\title{
Esterification Rates of Main Organic Acids in Wines
}

\author{
Takashi Shinohara, Jun-ichi Shimizu and Yoshimi Shimazu \\ Central Research Laboratories, Kikkoman Shoyu Co., Ltd. \\ 399, Noda, Noda-shi, Chiba-ken
}

Received June 19, 1979

\begin{abstract}
The esterification rates (ratio of the concentration of an acid in the neutral ethyl ester form to total concentration of the acid) of main organic acids in wines were determined to study the extent of ethyl ester formation of organic acids. The esterification rates ranged from zero to $24.6 \%$. The averaged values of table wines were from 6 to $16 \%$ for acetic and lactic acid, from 0.3 to $3.6 \%$ for succinic and malic acid, and from zero to $0.1 \%$ for tartaric acid. Sherries had higher esterification rates, about 1.6 to 6 times larger, than table wines. It was found that storage time and temperature influence the formation of ethyl esters, and it was suggested that the aging period required for the ester equilibrium is about one year for acetic and lactic acid, and more than two years for succinic, malic and tartaric acid. The possibility and the procedure to control wine quality during the aging process were discussed.
\end{abstract}

The formation of ethyl esters, such as ethyl esters of lactic, succinic, malic and tartaric acid, is one of the principal chemical changes taking place during aging of wine, and this esterification reaction favours the development of the odour and the taste of wine. ${ }^{1 \sim 3)}$ The ethyl esters are formed in the course of alcoholic fermentation and/or during aging of wine, ${ }^{4}$ and after a long period, they approach each ester's equilibrium. ${ }^{2)}$ The contents of ethyl esters in wine are regarded as the indices of length of aging., ${ }^{4)}$ Peynaud et $a .^{2}{ }^{2}$ examined the esterification of organic acids in model solutions and in wines; they concluded that the chemical esterification of organic acids produces largely acid esters and a small proportion of neutral esters. Otsuka et $a l .^{6}$ reported a significant increase of the volatile esters during storage of wine and other investigators $^{7 \sim 10)}$ also showed the formation or changes of ethyl esters during storage. However, little work has been done to estimate the esterification rates of individual organic acids in wine. In this work, the esterification rates of main organic acids were determined to find out the extent of esterification of organic acids in different types of wines. Also, the formation of ethyl esters and the esterification rates in model solutions and wines during storage were examined, then the effect of ester formation on the change of wine flavor during aging was discussed.

\section{MATERIALS AND METHODS}

Wines analysed. Japanese and foreign commercial table wines, new and old table wines, sparkling wines and sherries were used. The details of the wines are given in Tables I IV.

Gas chromatographic analysis of ethyl esters. A JEOL (Japan Electronic Optical Laboratories) type JGC-1100 apparatus with a flame ionisation detector was used. Concentrations of ethyl acetate and ethyl lactate were determined by the direct injection method. ${ }^{11}$ Diethyl esters of succinic, malic and tartaric acid were determined by injection of solvent extracts of wine. ${ }^{12}$ ) The chromatograms and the details of the methods are shown in Fig. 1. Using these methods, the esters were determined simply and accurate results (within $5 \%$ error) could be obtained.

Analysis of organic acids. The concentrations of acetic, lactic, succinic, malic and tartaric acid as free and fixed forms in wine were determined using a carboxylic acid analyzer, model S-603 (Seishin Pharmaceutical Company). ${ }^{13}$

Calculation of esterification rate. The concentration ( $\mathrm{g} / \mathrm{liter}$ ) of an acid in the form of the ethyl ester (neutral form) was divided by the total concentration $(\mathrm{g} / \mathrm{liter}$ ) of the acid and the ratio multiplied by 100 . The rate was expressed as per cent. 


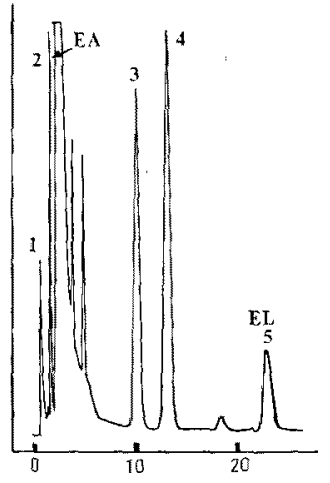

A. $P G-600\left(15^{\circ}\right), 95^{\circ} \mathrm{C}$
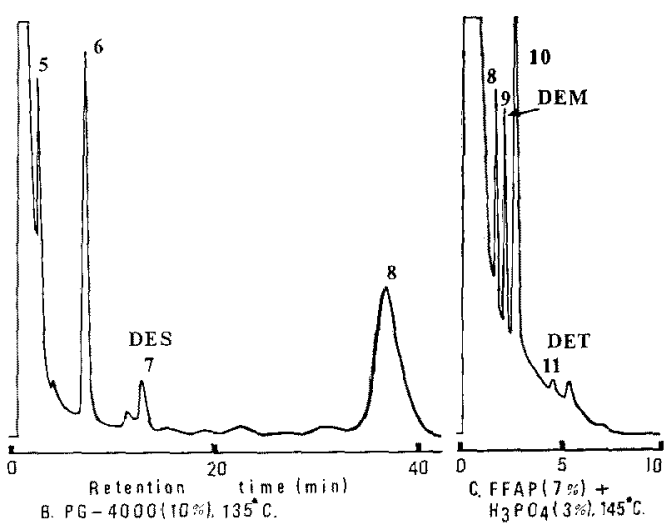

FIG. 1. Gas Chromatograms of Ethyl Esters in a White Wine.

Sample for gas chromatography: (A) Direct injection of wine. (B), (C) Solvent extract of wine: $5 \mathrm{ml}$ of wine was extracted with $3 \mathrm{ml}$ of solvent (ethyl acetate: $n$-pentane $=2: 1$ ) by shaking for ten minutes and $2 \mu$ of the solvent layer was injected into column.

Peaks: 1, acetaldehyde; 2, ethyl acetate; 3, $i$-amyl alcohol; 4, $n$-amyl alcohol (internal standard); 5, ethyl lactate; $6, n$-octyl alcohol (internal standard); 7, diethyl succinate; 8, 2-phenylethyl alcohol; 9, diethyl malate; 10 , monoethyl succinate; 11 , diethyl tartrate. Conditions: Column, $3 \mathrm{~mm}$ i.d.

$\times 2 \mathrm{~m}$ stainless steel column; carrier gas, $\mathrm{N}_{2} 30 \mathrm{ml} / \mathrm{min}$; detector, FID.

Model solutions and wines used for storage. (1) Model solutions: Organic acid mixtures in $14(\mathrm{v} / \mathrm{v}) \%$ ethanol solution were prepared with chemical reagents (Special degree, Wako Pure Chemical Industries, Ltd.), and the pH was adjusted with $5 \mathrm{~N}-\mathrm{KOH}$ (solutions No. 1 and 3 in Table V). The other two solutions (Nos. 2 and 4 in Table $\mathrm{V}$ ) were made by adding $30 \%$ (by volume) of the wine extracts to the solutions of organic acid mixtures (Nos. 1 and 3). The wine extracts were prepared as follows: Delaware wine (harvested in 1975) was evaporated to dryness in a water bath, and the residue was made up to the initial volume with $14(\mathrm{v} / \mathrm{v}) \%$ ethanol. The concentrations of acids in the solutions No. 3 and 4 were about two times higher than the solutions No. 1 and 2. (2) Wines: Two white wines, Zenkoji (1976) and Delaware (1975), were used in the experiment, and their chemical compositions were as follows (Zenkoji and Delaware): ethanol (v/v)\%: 13.2, 12.6; extract $(\%): 3.3,4.1 ;$ pH : both 3.3 ; total acid as tartaric acid (g/liter): 9.4, 11.1; total $\mathrm{SO}_{2}$ (mg/liter): 188,152 ; free $\mathrm{SO}_{2}(\mathrm{mg} / \mathrm{liter}): 42,38$. To both the wines, lactic acid ( $2 \mathrm{~g}$ /liter) was added at the beginning of storage to observe the formation of ethyl lactate.

\section{RESULTS AND DISCUSSION}

\section{Esterification rates of organic acids}

The contents of ethyl esters and organic acids, and the esterification rates are shown in Table I $\sim$ IV.

(1) Table wines. The esterification rates (abbreviated as E-rates) of Japanese and foreign table wines ranged from zero to $24.6 \%$, and the averaged values ranged from zero to $16.4 \%$ (Tables I, II). The E-rates differed between the organic acids: acetic and lactic acid had high E-rates with averages of 6.8 to $16.4 \%$, succinic and malic acid had low E-rates with averages of 0.3 to $3.6 \%$, and tartaric acid had the lowest E-rate with an average of zero to $0.13 \%$.

Some of the results are noteworthy in demonstrating the meaning of the E-rate: sample No. 1 (French wine, Table II) contained 434 $\mathrm{mg} /$ liter of ethyl lactate, while, sample No. 6 (German wine, Table II) contained only 22 $\mathrm{mg} /$ liter of the ester, whereas the E-rates of lactic acid in these wines were approximately the same level, 11.4 and $9.8 \%$, respectively. From this finding, it appears that the E-rate indicates more exactly the progress of esterifcation than the amounts of ethyl esters.

(2) New wines and old wines. The new wines (less than one year old) showed quite low E-rates of lactic, succinic, malic and tartaric acid: E-rates ranged from zero to $2.7 \%$ (Table III). However, acetic acid had a high E-rate with an average of $7.5 \%$. The old 
Table I. Esterification Rates of Organic Acios-(1) Jaranese Table Wines

\begin{tabular}{|c|c|c|c|c|c|c|c|c|c|c|c|c|c|c|c|c|}
\hline & & \multicolumn{3}{|c|}{ Acetic $^{a}$} & \multicolumn{3}{|c|}{ Lactic } & \multicolumn{3}{|c|}{ Succinic } & \multicolumn{3}{|c|}{ Malic } & \multicolumn{3}{|c|}{ Tartaric } \\
\hline & & EA & A & ER & EL & $\mathrm{L}$ & ER & DES & $\mathbf{S}$ & ER & DEM & $\mathbf{M}$ & ER I & $\mathrm{DET}$ & $\mathrm{T}$ & ER \\
\hline & & \multicolumn{3}{|c|}{$\mathrm{g} /$ liter $\mathrm{g} /$ liter $\%$} & \multicolumn{3}{|c|}{$\mathrm{mg} /$ liter $\mathrm{g} /$ liter $\%$} & \multicolumn{3}{|c|}{$\mathrm{mg} /$ liter $\mathrm{g} /$ liter $\%$} & \multicolumn{3}{|c|}{$\mathrm{mg} /$ liter $\mathrm{g} /$ liter $\%$} & \multicolumn{3}{|c|}{$\mathrm{mg} /$ liter $\mathrm{g} /$ liter $\%$} \\
\hline 1 & White wine & 55 & 0.47 & 7.9 & 63 & 0.82 & 5.8 & 7 & 0.45 & 1.0 & 16 & 1.16 & 0.97 & 0 & 1.70 & 0 \\
\hline 2 & $n$ & 49 & 0.38 & 8.7 & 112 & 0.73 & 11.6 & 7 & 0.42 & 1.1 & 16 & 1.17 & 0.96 & 5 & 1.93 & 0.18 \\
\hline 3 & $"$ & 41 & 0.34 & 8.2 & 117 & 0.80 & 11.1 & 16 & 0.41 & 2.6 & 15 & 1.28 & 0.82 & 0 & 1.69 & 0 \\
\hline 4 & $"$ & 67 & 0.52 & 8.7 & 269 & 1.34 & 15.2 & 12 & 0.45 & 1.8 & 16 & 1.07 & 1.05 & 5 & 2.13 & 0.17 \\
\hline 5 & $n$ & 59 & 0.48 & 8.3 & 53 & 0.44 & 9.1 & 7 & 0.43 & 1.1 & 28 & 1.72 & 1.14 & 5 & 2.20 & 0.16 \\
\hline \multirow[t]{2}{*}{6} & $"$ & 97 & 0.67 & 9.8 & 50 & 0.76 & 5.0 & 17 & 0.55 & 2.0 & 33 & 1.76 & 1.32 & 5 & 1.81 & 0.20 \\
\hline & $X$ & & & 8.6 & & & 9.6 & & & 1.6 & & & 1.04 & & & 0.11 \\
\hline 7 & Rose wine & 67 & 0.55 & 8.2 & 111 & 0.89 & 9.5 & 9 & 0.51 & 1.1 & 15 & 1.21 & 0.87 & 5 & 1.84 & 0.19 \\
\hline 8 & " & 46 & 0.49 & 6.3 & 69 & 0.64 & 8.2 & 8 & 0.51 & 1.0 & 14 & 1.43 & 0.63 & 0 & 2.25 & 0 \\
\hline \multirow[t]{2}{*}{9} & $"$ & 30 & 0.33 & 6.1 & 80 & 1.14 & 5.3 & 9 & 0.51 & 1.1 & 14 & 1.27 & 0.77 & 5 & 2.26 & 0.16 \\
\hline & $\bar{X}$ & & & 6.8 & & & 7.6 & & & 1.0 & & & 0.77 & & & 0.11 \\
\hline 10 & Red wine & 7 & 0.86 & 7.8 & 127 & 1.16 & 8.3 & 12 & 0.68 & 1.1 & 11 & 1.21 & 0.87 & 0 & 1.68 & 0 \\
\hline 11 & $"$ & 105 & 0.80 & 8.9 & 139 & 1.16 & 9.1 & 12 & 0.64 & 1.2 & 8 & 0.69 & 0.81 & 0 & 1.56 & 0 \\
\hline 12 & $"$ & 99 & 0.79 & 8.5 & 191 & 1.41 & 10.3 & 20 & 0.61 & 2.2 & 7 & 0.47 & 1.05 & 0 & 1.48 & 0 \\
\hline \multirow[t]{2}{*}{13} & $"$ & 104 & 0.70 & 10.1 & 168 & 0.94 & 13.6 & 28 & 0.71 & 2.6 & 9 & 0.72 & 0.88 & 0 & 2.04 & 0 \\
\hline & $X$ & & & 8.8 & & & 10.3 & & & 1.7 & & & 0.84 & & & U \\
\hline & iges $(X=13$, & & $6.1 \sim$ & 10.1 & & $5.0 \sim$ & 15.2 & & 1.0 & -2.6 & & 0.62 & -1.32 & & $0 \sim 0$ & 20 \\
\hline
\end{tabular}

$\mathrm{EA}$, ethyl acetate; $\mathrm{A}$, acetic acid; ER, esterification rate $(\%)=$ concentration $(\mathrm{g} / \mathrm{liter})$ of acid in the form of neutral ethyl ester/Total concentration ( $\mathrm{g} /$ liter) of acid $\times 100 ; \mathrm{EL}$, ethyl lactate; L, lactic acid; DES, diethyl succinate; S, succinic acid; DEM, diethyl malate; M, malic acid; DET, diethyl tartrate; $\mathrm{T}$, tartaric acid.

Table II. Esterification Rates of Organic Acids-(2) Foreign Table Wines ${ }^{\alpha}$

\begin{tabular}{|c|c|c|c|c|c|c|c|c|c|c|c|c|c|c|c|c|}
\hline & & \multicolumn{3}{|c|}{ Acetic $^{b}$} & \multicolumn{3}{|c|}{ Lactic } & \multicolumn{3}{|c|}{ Succinic } & \multicolumn{3}{|c|}{ Malic } & \multicolumn{3}{|c|}{ Tartaric } \\
\hline & & $\mathrm{EA}$ & A & ER & EL & $\mathrm{L}$ & ER & DES & $\mathrm{S}$ & ER & $\mathrm{DEM}$ & $\mathrm{M}$ & $\mathrm{ER}$ & DET & $\mathrm{T}$ & ER \\
\hline & & \multicolumn{12}{|c|}{$\mathrm{mg} /$ liter $\mathrm{g} / \mathrm{liter} \% \mathrm{mg} / \mathrm{liter} \mathrm{g} / \mathrm{liter} \% \mathrm{mg} / \mathrm{liter} \mathrm{g} / \mathrm{liter} \% \mathrm{mg} / \mathrm{liter} \mathrm{g} / \mathrm{liter} \%$} & \multicolumn{3}{|c|}{$\mathrm{mg} / \mathrm{liter} \mathrm{g} / \mathrm{liter} \%$} \\
\hline \multicolumn{17}{|c|}{ White wine } \\
\hline 1 & French wine & 94 & 0.48 & 13.3 & 434 & 2.90 & 11.4 & 18 & 0.51 & 2.3 & 13 & 0.55 & 1.6 & 5 & 2.53 & 0.14 \\
\hline 2 & $n$ & 47 & 0.43 & 7.4 & 188 & 1.30 & 11.0 & 21 & 0.59 & 2.4 & 32 & 1.44 & 1.5 & 12 & 2.12 & 0.41 \\
\hline 3 & $"$ & 91 & 0.73 & 8.4 & 314 & 2.15 & 11.1 & 19 & 0.48 & 2.6 & 38 & 2.07 & 1.2 & 8 & 3.27 & 0.17 \\
\hline 4 & German wine & 41 & 0.49 & 5.6 & 172 & 2.07 & 6.3 & 9 & 0.46 & 1.3 & 6 & 1.20 & 0.3 & 0 & 3.15 & 0 \\
\hline 5 & $"$ & 47 & 0.47 & 6.8 & 24 & 0.21 & 8.7 & 9 & 0.49 & 1.2 & 8 & 3.84 & 0.1 & 0 & 3.41 & 0 \\
\hline 6 & $" \prime$ & 96 & 0.70 & 9.3 & 22 & 0.17 & 9.8 & 34 & 0.58 & 3.9 & 50 & 2.63 & 1.3 & 5 & 1.03 & 0.35 \\
\hline 7 & Yugoslav wine & 27 & 0.28 & 6.5 & 132 & 0.99 & 10.1 & 14 & 0.51 & 1.8 & 0 & 1.12 & 0 & 0 & 1.50 & 0 \\
\hline \multirow[t]{2}{*}{8} & $n$ & 46 & 0.42 & 7.4 & 195 & 0.94 & 15.8 & 13 & 0.37 & 2.3 & 0 & 1.65 & 0 & 0 & 2.16 & 0 \\
\hline & $\bar{X}$ & & & 8.0 & & & 10.5 & & & 2.2 & & & 0.75 & & & 0.13 \\
\hline
\end{tabular}

\begin{tabular}{|c|c|c|c|c|c|c|c|c|c|c|c|c|c|c|c|}
\hline \multicolumn{16}{|c|}{ Red wine } \\
\hline 9 & French wine & 93 & 1.15 & 5.5 & 208 & 1.3711 .5 & 28 & 0.41 & 4.6 & 7 & 0.40 & 1.2 & 0 & 1.58 & 0 \\
\hline 10 & $n$ & 114 & 0.67 & 11.5 & 235 & $1.02 \quad 17.5$ & 28 & 0.70 & 2.7 & 0 & 0.04 & 0 & 0 & 1.56 & 0 \\
\hline 11 & $n$ & 127 & 0.64 & 13.5 & 340 & 1.0524 .6 & 36 & 0.59 & 4.1 & 0 & 0.07 & 0 & 0 & 2.97 & 0 \\
\hline 12 & $"$ & 98 & 0.69 & 9.6 & 179 & $1.12 \quad 12.1$ & 27 & 0.61 & 3.0 & 0 & 0.06 & 0 & 0 & 2.03 & 0 \\
\hline & $\bar{X}$ & & & 10.0 & & 16.4 & & & 3.6 & & & 0.3 & & & 0 \\
\hline Ran & $\operatorname{ges}(X=12, \%)$ & & $5.5 \sim$ & 13.5 & & $6.3 \sim 24.6$ & & 1.2 & 4.6 & & & -1.6 & & $0 \sim 0$. & \\
\hline
\end{tabular}

a Origin of the wines: No. 1 and 2, Chablis 1972 and 1974; No. 3, Montrachet 1972; No. 4, Mosel QbA 1976; No. 5, Rheingau Ausless 1976; No. 6, Rheingau Beerenauslese 1971; No. 7 and 8, both 1975; No. 9 and 10, Bordeaux 1974 and 1971; No. 11 and 12, Bourgogne; both 1970.

b See footnote of Table I. 
Table III. Esterification Rates of Origanic Acids-(3) New Wines and Old Wines ${ }^{a}$

\begin{tabular}{|c|c|c|c|c|c|c|c|c|c|c|c|c|c|c|c|c|}
\hline & & \multicolumn{3}{|c|}{ Acetic $^{b}$} & \multicolumn{3}{|c|}{ Lactic } & \multicolumn{3}{|c|}{ Succinic } & \multicolumn{3}{|c|}{ Malic } & \multicolumn{3}{|c|}{ Tartaric } \\
\hline & & $\overline{\mathrm{EA}}$ & A & $\overline{E R}$ & $\mathrm{EL}$ & $\mathrm{L}$ & $\overline{E R}$ & DES & $\mathrm{S}$ & $\mathrm{ER}$ & DEM & $M$ & ER & DET & $T$ & ER \\
\hline & & \multicolumn{15}{|c|}{$\mathrm{mg} /$ liter $\mathrm{g} /$ liter $\% \mathrm{mg} /$ liter $\mathrm{g} /$ liter $\% \mathrm{mg} /$ liter $\mathrm{g} /$ liter $\% \mathrm{mg} /$ liter $\mathrm{g} /$ liter $\% \mathrm{mg} /$ liter $\mathrm{g} / \mathrm{liter} \%$} \\
\hline \multicolumn{17}{|c|}{$\begin{array}{l}\text { New wines: } \\
\text { White wine } 1977\end{array}$} \\
\hline 1 & Koshu & 37 & 0.43 & 5.8 & 0 & 0.18 & 0 & 0 & 0.32 & 0 & 0 & 3.01 & 0 & 0 & 4.62 & 0 \\
\hline 2 & Zenkoji & 32 & 0.20 & 10.8 & 0 & 0.20 & 0 & 0 & 1.33 & 0 & 0 & 3.46 & 0 & 0 & 1.31 & 0 \\
\hline 3 & Riesling & 39 & 0.64 & 4.1 & 0 & 0.09 & 0 & 0 & 0.52 & 0 & 0 & 5.81 & 0 & 0 & 2.28 & 0 \\
\hline 4 & Chardonnay & 22 & 0.26 & 5.7 & 0 & 0.05 & 0 & 0 & 0.53 & 0 & 0 & 3.08 & 0 & 0 & 3.90 & 0 \\
\hline 5 & $\begin{array}{l}\text { German wine } \\
\text { Red wine } 1977\end{array}$ & 28 & 0.19 & 10.0 & 36 & 2.26 & 1.2 & 0 & 0.32 & 0 & 0 & 4.10 & 0 & 0 & 1.96 & 0 \\
\hline 6 & Cabernet-S. & 42 & 0.20 & 14.3 & 10 & 0.29 & 2.6 & 7 & 0.92 & 0.5 & 0 & 4.68 & 0 & 0 & 2.54 & 0 \\
\hline \multirow[t]{2}{*}{7} & Muscat Bail. & 33 & 1.04 & 2.1 & 74 & 2.07 & 2.7 & 11 & 0.93 & 0.8 & 0 & 0.14 & 0 & 0 & 1.13 & 0 \\
\hline & $\begin{array}{l}\text { Range and mean } \\
\text { values }(\%)\end{array}$ & 2.1 & $\sim 14.3$ & $; 7.5$ & & $0 \sim 2.7$ & $; 0.9$ & & $0 \sim 0.8$ & $; 0.1$ & & & 0 & & & 0 \\
\hline \multicolumn{17}{|c|}{$\begin{array}{l}\text { Old wines: } \\
\text { White wine }\end{array}$} \\
\hline 1 & Koshu 1967 & 86 & 0.80 & 7.3 & 7 & 0.09 & 5.9 & 13 & 0.23 & 3.8 & 33 & 2.43 & 0.9 & 8 & 2.92 & 0.19 \\
\hline 2 & Old wine & 109 & 1.02 & 7.2 & 88 & 0.66 & 10.1 & 28 & 0.63 & 3.0 & 28 & 1.57 & 1.2 & 34 & 2.30 & 1.07 \\
\hline 3 & $\begin{array}{l}\text { Bordeaux } 1962 \\
\text { Red wine }\end{array}$ & 260 & 2.15 & 8.2 & 34 & 0.33 & 7.8 & 50 & 0.94 & 3.6 & 30 & 1.98 & 1.0 & 0 & 2.51 & 0 \\
\hline 4 & Bordeaux 1959 & 119 & 0.79 & 10.2 & 206 & 1.50 & 10.4 & 38 & 0.59 & 4.3 & 0 & 0.03 & 0 & 0 & 1.48 & 0 \\
\hline 5 & Bordeaux 1961 & 157 & 0.77 & 13.8 & 247 & 0.96 & 19.6 & 27 & 0.66 & 2.7 & 0 & 0.04 & 0 & 5 & 1.28 & 0.28 \\
\hline \multirow[t]{2}{*}{6} & Bourgogne 1961 & 140 & 0.87 & 10.9 & 120 & 1.05 & 8.7 & 30 & 0.61 & 3.3 & 0 & 0.05 & 0 & 0 & 1.82 & 0 \\
\hline & $\begin{array}{l}\text { Range and mean } \\
\text { values }(\%)\end{array}$ & ${ }^{n} 7$. & 13.8 & 99.6 & 5.9 & 6 & 10.4 & 2.1 & $7 \sim 4.3$ & $: 3.4$ & & $0 \sim 1.2$ & $; 0.5$ & & $\sim 1.07$ & $; 0.25$ \\
\hline
\end{tabular}

Table IV. Esterification Rates of Organic Acids-(4) Sparking Wines and Sherries

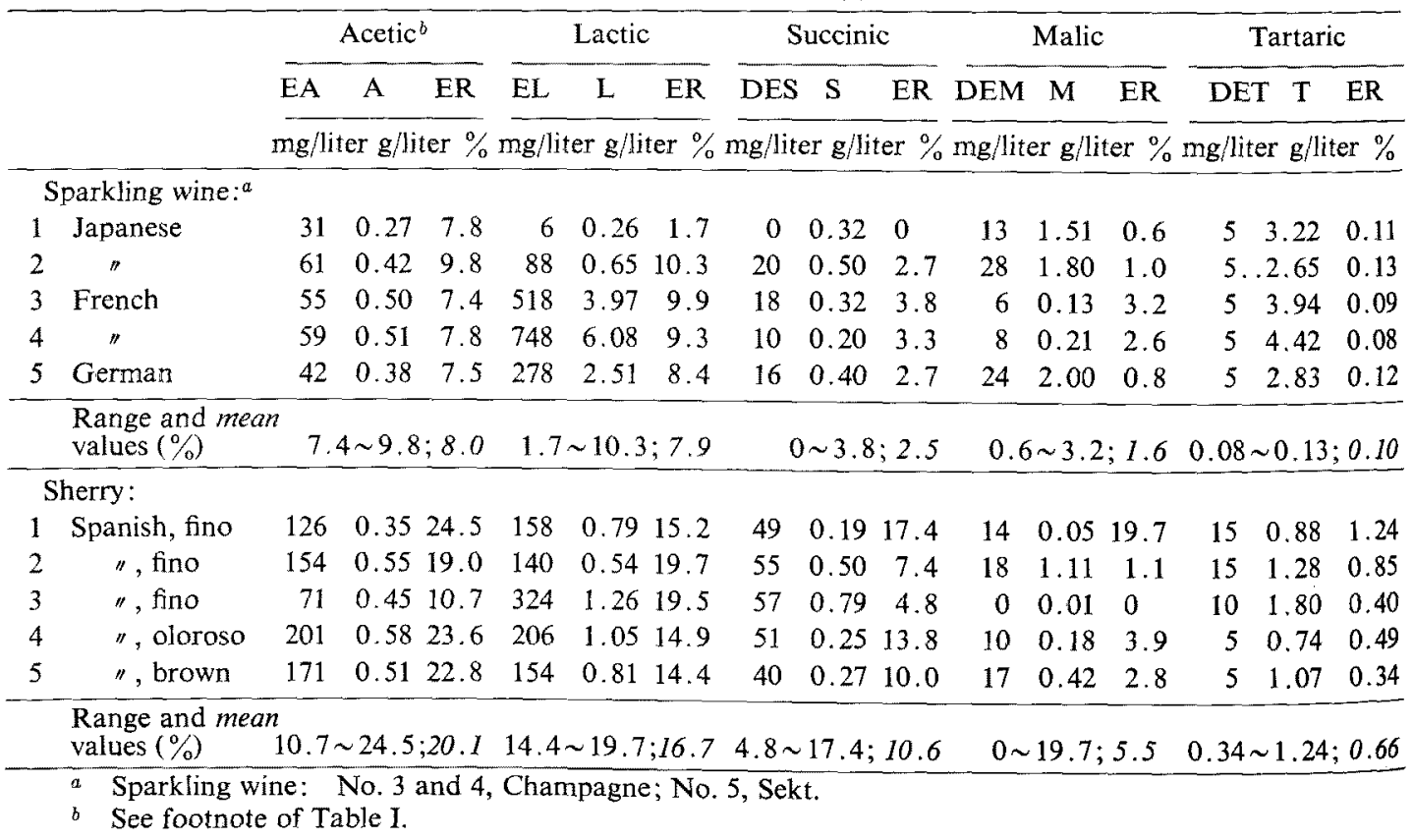


wines (more than ten years old) had nearly the same E-rates as the table wines (Tables I, II) of acetic, lactic, succinic and malic acid, while, tartaric acid showed a higher E-rate (Table III) than that of the table wines (Tables I, II).

It was recognized that in some aged wines, the E-rates of malic and tartaric acid were zero per cent, in spite of normal contents of these acids (Tables II, III). This fact suggests that the esterification of organic acids is affected not only by the aging time but also by other factors, such as the ionization constant of the organic acid and $\mathrm{pH} .^{2}$

(3) Sparkling wines. The E-rates (Table IV) were almost the same as those of the table wines (Table I, II). This indicates that there is no significant difference between sparkling wines and table wines in the composition of ethyl esters.

(4) Sherries. Spanish sherries were used to estimate the E-rates (Table IV). The sherries had apparently higher E-rates than the table wines (Tables I, II); the average E-rates of acetic and lactic acid were 20.1 and $16.7 \%$, that is 1.6 to 3 times larger than the table wines; those of succinic, malic and tartaric acid were $10.6,5.5$ and $0.66 \%$, respectively, that is 4 to 6 times larger than the table wines. Thus in the sherries, the E-rates of dibasic acids were more increased than those of monobasic acids. This result indicates that dynamic esterification of organic acids takes place in sherry, and one reason for the characteristic flavor of sherry is the large amounts of ethyl esters. High Erates in sherry seem to result from high ethanol contents; sherry generally contains about 17 to $20(\mathrm{v} / \mathrm{v}) \%$ of ethanol, ${ }^{14)}$ however, table wine contains about $10(\mathrm{v} / \mathrm{v}) \%$ of ethanol, so the content of sherry is about two times higher than that of table wine.

\section{Ethyl ester formation in model solutions}

The time course of ester formation in the solutions No. 1 and 3 is shown in Fig. 2. The ethyl esters of acetic and lactic and were formed rapidly; the ethyl acetate reached the maximum level after three months, and the
Table V. Composition of Model Solutions ${ }^{\alpha}$

\begin{tabular}{|c|c|c|c|c|}
\hline & \multicolumn{4}{|c|}{ Solution No. } \\
\hline & 1 & 2 & 3 & 4 \\
\hline \multirow{2}{*}{$\begin{array}{l}\text { Ethanol }(v / v \%) \\
\text { pH }\end{array}$} & 14.0 & 14.0 & 14.0 & 14.0 \\
\hline & 3.4 & 3.3 & 3.2 & 3.2 \\
\hline Titrable acidity ${ }^{b}$ & 6.2 & 8.5 & 11.3 & 13.5 \\
\hline Acetic acid $(")$ & 0.62 & 0.69 & 1.51 & 1.18 \\
\hline Lactic acid $(n)$ & 0.90 & 0.96 & 2.27 & 1.75 \\
\hline Succinic acid (") & 1.14 & 1.30 & 2.87 & 2.26 \\
\hline Malic acid (") & 2.14 & 3.35 & 5.61 & 5.30 \\
\hline Tartaric acid ("I) & 2.22 & 3.37 & 3.91 & 3.57 \\
\hline \multicolumn{5}{|c|}{$\begin{array}{l}\text { Model solution: No. } 1 \text { and } 3 \text { : A mixture of } \\
\text { organic acids and } 14(\mathrm{v} / \mathrm{v}) \% \text { ethanol. pH was } \\
\text { adjusted with } 5 \mathrm{~N}-\mathrm{KOH} \text {. No. } 2 \text { and } 4 \text {, a mixture } \\
\text { of the extract from Delaware wine and the acid } \\
\text { solution (No. } 1 \text { or } 3 \text { ) in a } 30: 70 \text { ratio. }\end{array}$} \\
\hline$b \quad$ Titrable acidi & expre & as ta & ic ac & \\
\hline
\end{tabular}

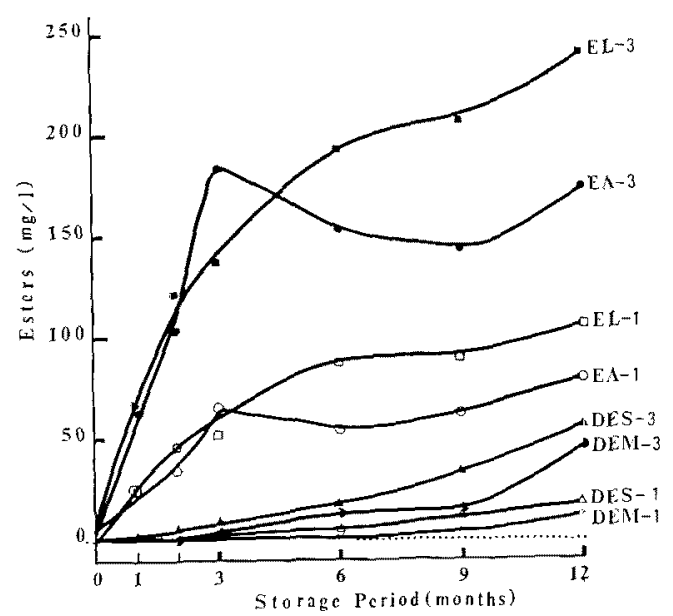

FIG. 2. Formation of Ethyl Esters in the Model Solutions (Nos. 1 and 3) during Storage at Room Temperature $\left(20^{\circ} \pm 5^{\circ} \mathrm{C}\right)$.

EA-1, ethyl acetate in the model solution No. 1; EL-3, ethyl lactate in the model solution No. 3; DES, diethyl succinate; DEM, diethyl malate. Composition of model solutions: See Table V.

ethyl lactate nearly reached the maximum level between six to twelve months. To diethyl esters of succinic and malic acid were formed slowly during the storage, however, diethyl tartrate was not formed.

The E-rates of the solutions stored for twelve months are shown in Table VI. The average E-rates of the model solutions were approximately the same as those of table wines (Tables 
Table Vi. Esterification Rates of Organic Acids in the Model Solutions ${ }^{a}$ STORED FOR 12 MONTHS

\begin{tabular}{|c|c|c|c|c|c|c|c|c|c|c|c|c|c|c|}
\hline & \multicolumn{3}{|c|}{ Acetic $^{b}$} & \multicolumn{2}{|r|}{ Lactic } & \multicolumn{3}{|c|}{ Succinic } & \multicolumn{3}{|c|}{ Malic } & \multicolumn{3}{|c|}{ Tartaric } \\
\hline & $\mathrm{EA}$ & A & $\mathrm{ER}$ & $\overline{\mathrm{EL}}$ & L ER & DES & S & $\mathrm{ER}$ & DEM & $1 \mathrm{M}$ & ER & DET & $\mathrm{T}$ & ER \\
\hline & \multicolumn{14}{|c|}{$\mathrm{mg} /$ liter $\mathrm{g} /$ liter $\% \mathrm{mg} /$ liter $\mathrm{g} /$ liter $\% \mathrm{mg} /$ liter $\mathrm{g} /$ liter $\% \mathrm{mg} /$ liter $\mathrm{g} /$ liter $\% \mathrm{mg} /$ liter $\mathrm{g} /$ liter $\%$} \\
\hline \multicolumn{15}{|c|}{ Room temp. ${ }^{c}$} \\
\hline No. 1 & 79 & 0.64 & 8.6 & 106 & $0.92 \quad 8.9$ & 17 & 1.14 & 1.0 & 12 & 2.14 & 0.3 & 0 & 2.22 & 0 \\
\hline 2 & 84 & 0.69 & 8.2 & 130 & $0.96 \quad 10.3$ & 31 & 1.30 & 1.6 & 33 & 3.35 & 0.6 & 0 & 3.37 & 0 \\
\hline 3 & 174 & 1.51 & 7.8 & 242 & $2.27 \quad 8.1$ & 56 & 2.87 & 1.3 & 46 & 5.61 & 0.5 & 0 & 3.91 & 0 \\
\hline 4 & 190 & 1.18 & 10.9 & 260 & 1.7511 .3 & 57 & 2.26 & 1.7 & 62 & 5.30 & 0.8 & 0 & 3.57 & 0 \\
\hline $\bar{X}$ & & & 8.8 & & 9.6 & & & 1.4 & & & 0.6 & & & 0 \\
\hline \multicolumn{15}{|l|}{$30^{\circ} \mathrm{C}^{d}$} \\
\hline No. 1 & 84 & 0.64 & 9.2 & 120 & $0.90 \quad 10.1$ & 37 & 1.14 & 2.2 & 30 & 2.14 & 0.9 & 0 & 2.22 & 0 \\
\hline 2 & 86 & 0.69 & 8.4 & 170 & $0.96 \quad 13.4$ & 52 & 1.30 & 2.7 & 49 & 3.35 & 1.0 & 0 & 3.37 & 0 \\
\hline 3 & 172 & 1.51 & 7.7 & 254 & $2.27 \quad 8.5$ & 94 & 2.87 & 2.2 & 65 & 5.61 & 0.8 & 0 & 3.91 & 0 \\
\hline 4 & 190 & 1.18 & 10.9 & 266 & 1.7511 .5 & 110 & 2.26 & 3.3 & 80 & 5.30 & 1.0 & 0 & 3.57 & 0 \\
\hline $\bar{X}$ & & & 9.0 & & 10.8 & & & 2.6 & & & 0.9 & & & 0 \\
\hline
\end{tabular}

${ }^{a}$ See Table V. ${ }^{b}$ See footnote of Table I. ${ }^{c}$ Stored at room temperature $\left(20^{\circ} \pm 5^{\circ} \mathrm{C}\right)$.

${ }^{a}$ Stored at $30^{\circ} \mathrm{C}$.

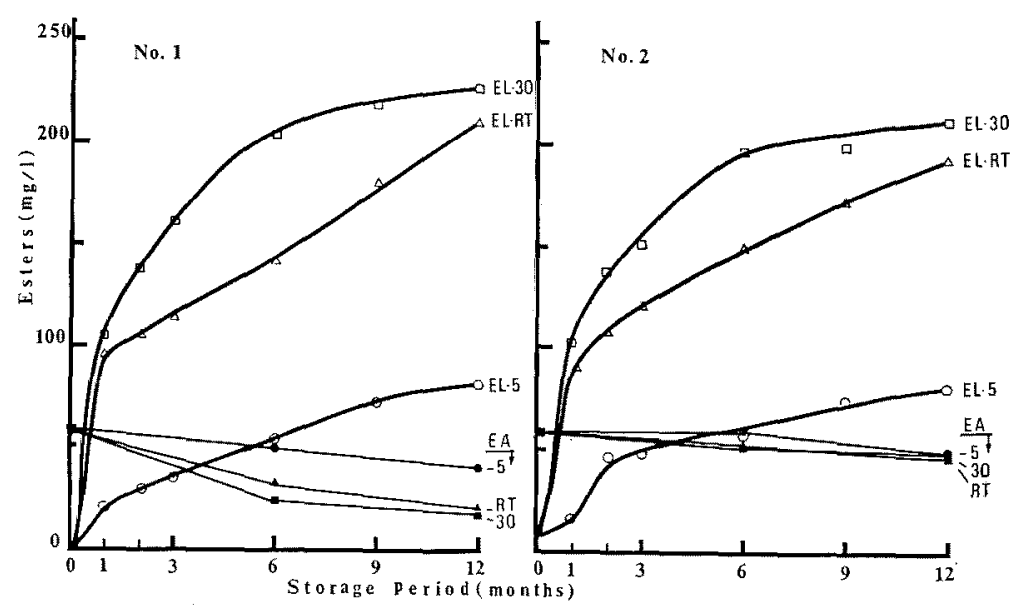

Fig. 3. Change of Ethyl Esters in the Wines during Storage at $5^{\circ} \mathrm{C}$, Room temperature and $30^{\circ} \mathrm{C}$. The wines: No. 1, Zenkoji 1976; No. 2, Delaware 1975. EA, ethyl acetate; EL, ethyl lactate; $5,5^{\circ} \mathrm{C} ; \mathrm{RT}$, room temperature $\left(20^{\circ} \pm 5^{\circ} \mathrm{C}\right) ; 30,30^{\circ} \mathrm{C}$.

I, II). High storage temperatures $\left(30^{\circ} \mathrm{C}\right.$ and room temperature: $20^{\circ} \pm 5^{\circ} \mathrm{C}$ ) made the E-rates of organic acids increase. The difference in E-rate between $30^{\circ} \mathrm{C}$ and room temp. was small for acetic and lactic acid, while for succinic and malic acid, it was fairly large. This result suggests that the esterification of acetic and lactic acid approached the ester equilibrium after one year, but that of succinic and malic acid was not near the ester equilibrium even after one year. Peynaud et al. ${ }^{15\rangle}$ found that the E-rate of lactic acid in wines was 12 to $14 \%$ and they considered that the period of aging needed to reach ester equilibrium of lactic acid is one year. The results of this work well agree with their observation.

\section{Ethyl ester formation in wines}

The changes of ethyl esters of acetic and lactic acid in the wines stored at $5^{\circ} \mathrm{C}$, room 
Table VII. Esterification Rates of Organic Acids in the Wines ${ }^{a}$ STORED FOR 12 MONTHS

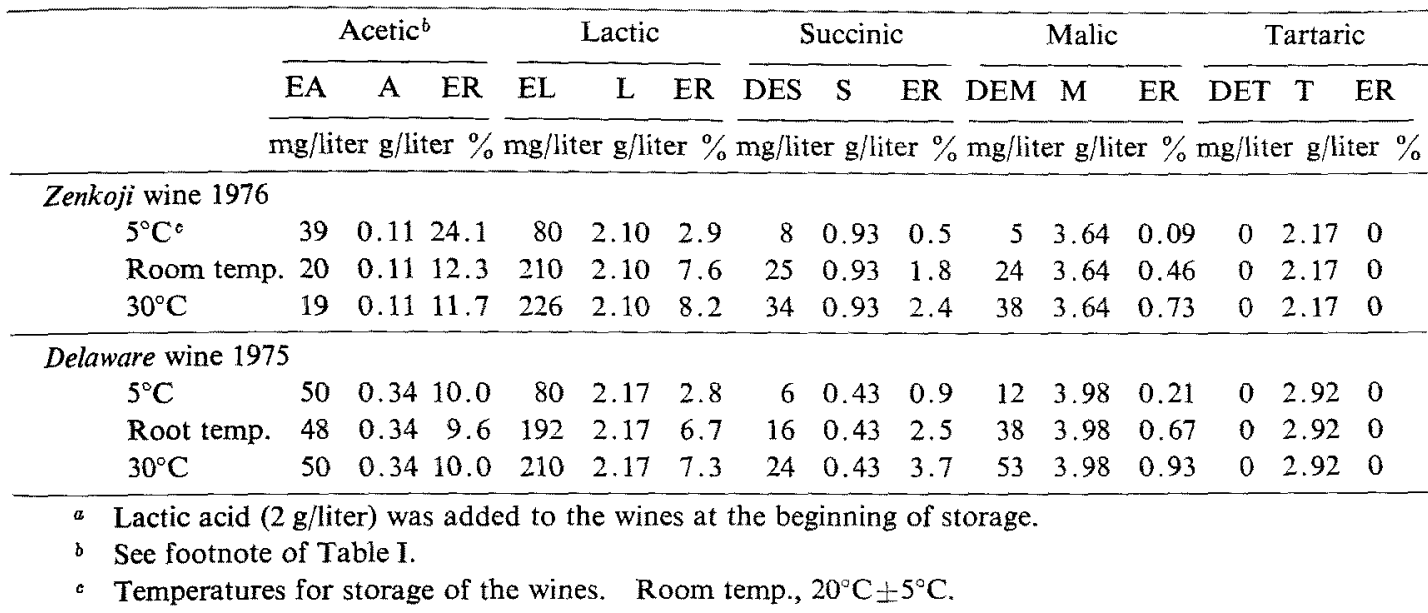

temp. $\left(20^{\circ} \pm 5^{\circ} \mathrm{C}\right)$ and $30^{\circ} \mathrm{C}$ are shown in Fig. 3. Ethyl lactate was formed rapidly and the speed of the formation was enhanced by increasing temperatures (Fig. 3); the speed at $30^{\circ} \mathrm{C}$ was about two or three times faster than that at room temp., while, the speed at $5^{\circ} \mathrm{C}$ was very slow, less than one tenth of that at room temp. From this result, the period necessary to approach the ester equilibrium of lactic acid seems to be six months at $30^{\circ} \mathrm{C}$ and twelve months at room temp., and this time of aging agreed with the results of the model solutions (Fig. 2).

A significant decrease of ethyl acetate was observed in the No. 1 wine and the loss in content was larger with increasing temperatures $\left(30^{\circ} \mathrm{C}\right.$ and room temp.). The same tendency was shown for the No. 2 wine (Fig. 3).

The E-rates of the wines stored for twelve months are shown in Table VII. The E-rates of acetic acid in the No. 1 wine stored at room temp. and $30^{\circ} \mathrm{C}$ were 12.3 and $11.7 \%$, respectively. It seems that acetic acid in these wines nearly reached the ester equilibrium, because the E-rate of acetic acid in table wines was about $10 \%$ (Tables I, II). In the No. 2 wine, the E-rates of acetic acid at different temperatures were the same, that is $10 \%$. It seems that acetic acid in these wines reached the ester equilibrium.

It is well known that ethyl acetate is princi- pally formed via a biochemical reaction (in yeast cells) during alcoholic fermentation, ${ }^{16}{ }^{3}$ so it can be considered that the change of ethyl acetate during storage depends on the extent of esterification of acetic acid in wine after the fermentation: when the E-rate exceeds the level of the ester equilibrium, ethyl acetate is going to decrease, on the other hand, if the E-rate is lower than the level of the ester equilibrium, ethyl acetate is going to increase. Thus it appears that the E-rates of organic acids are converging to the levels of ester equilibrium during aging.

The E-rates of lactic, succinic and malic acid in the wines stored at room temp. for twelve months (Table VII) were almost the same as those of table wines (Tables I, II), and the Erates at $30^{\circ} \mathrm{C}$ were higher than those of at room temp.; diethyl tartrate was not formed in the wines. These results show the same tendency as for the model solutions (Table VI).

\section{Formation of ethyl esters during aging and their} influence on wine quality

The results described above show that the formation of ethyl esters of main organic acids in wine is accelerated with increased temperatures and the esterification is achieved with time, however, in some cases, ethyl acetate is decreased during aging. The E-rates of the organic acids and the periods required to reach 
the ester equilibrium differed between acids and between wines. It seems that the period of aging necessary to approach the ester equilibrium of main organic acids as neutral ethyl esters is one to ten years at ordinary temperatures.

It is suggested that wines containing large quantities of organic acids will form the bouquet and the odor well with the formation of large amounts of ethyl esters during aging, while, it is quite possible that large quantities of acetic acid in wine cause abundant formation of ethyl acetate that deteriorates the wine flavor; when a fresh and young flavor in wine is expected, it is recommended that the wines should be consumed soon after fermentation, or should be stored at low temperature $\left(0 \sim 10^{\circ} \mathrm{C}\right)$ to minimize the change of ethyl esters.

The average E-rates of acetic and lactic acid were about $10 \%$ in table wines, however, those of the dibasic acids in the neutral ethyl ester form were low, from zero to $3 \%$. The E-rates of dibasic acids estimated by Peynaud ${ }^{21}$ were about $10 \%$ at the ester equilibrium; it is suggested that the difference between the E-rates of this work and those of Peynaud's results from a large amount of monoethyl ester formation of succinic, malic and tartaric acid.

Acknowledgments. The authors wish to thank Drs. T. Yokotsuka, N. Iguchi and F. Yoshida of Kikkoman Shoyu Co., Ltd. for their encouragement.

\section{REFERENCES}

1) K. Otsuka, J. Brew. Society Japan, 58, 504 (1963).

2) J. Ribéreau-Gayon et E. Peynaud, "Traité D’OEnologie," Vol. 2, Dunod, Paris, 1966, p. $239 \sim 249$.

3) F. Malik, Vinoharad, 13, 88 (1975), [Food Sci. Technol. Abst., 8, $1 \mathrm{H} 89$ (1976)].

4) M. A. Amerine and M. A. Joslyn, "Table Wines," University of California Press, Los Angeles, 1970, p. $445 \sim 449$.

5) M. Watanabe and Y. Shimazu, J. Ferment. Technol., 56, 114 (1978).

6) K. Otsuka, H. Masuda and H. Furuya, Bull. Research Inst. Ferment. Yamanashi Univ., No. 2, 27 (1955).

7) A. D. Webb, R. E. Kepner and L. Maggiora, Am. J. Enol. Viticult., 20, 16 (1969).

8) D. J. Stern, D. Guadagni and K. L. Stevens, ibid., 26, 208 (1975).

9) R. F. Simpson, Vitis, 17, 274 (1978).

10) J. Shimizu and M. Watanabe, Nippon Nōgeikagaku Kaishi, 52, 289 (1978).

11) T. Shinohara and M. Watanabe, Agric. Biol. Chem., 40, 2475 (1976).

12) idem., Nippon Nögeikagaku Kaishi, 53, 219 225 (1979).

13) Y. Shimazu and M. Watanabe, Wein-wiss., 31, 45 (1976).

14) M. A. Amerine, H. W. Berg and W. V. Cruss, "The Technology of Wine Making," The Avi Publishing Co., Connecticut, 1967, p. 433.

15) E. Peynaud, S. Lafon-Lafourcade and G. Guimberteau, Am. J. Enol. Viticult., 17, 302 (1966).

16) K. Yoshizawa, J. Brew. Society Japan, 61, 481 (1966). 